\section{Efficacy of Metamifop for the Control of Common Bermudagrass}

\author{
Tyler Cooper ${ }^{1}$, Leslie L. Beck², Chase M. Straw ${ }^{3}$, \\ and Gerald M. Henry ${ }^{3,4}$
}

ADDITIONAL INDEX WORDs. golf course, turfgrass, weed management

SumMARY. Metamifop is a postemergence aryloxyphenoxypropionic acid herbicide used for the control of annual and perennial grass weeds in cereal crops and rice (Oryza sativa L.). Previous research observed creeping bentgrass (Agrostis stolonifera $\mathrm{L}$.) tolerance to applications of metamifop, suggesting utilization for the removal of encroaching bermudagrass (Cynodon Rich.) from creeping bentgrass putting greens with little to no phytotoxicity. Therefore, the objective of our research was to evaluate the efficacy of metamifop for common bermudagrass [Cynodon dactylon (L.) Pers.] control in a greenhouse environment. Experiments were conducted at the Plant and Soil Science greenhouse facility at Texas Tech University in Lubbock in 2011 and 2012. 'Riviera' and 'Savannah' common bermudagrass were seeded at $218 \mathrm{lb}$ /acre into 4 -inch square pots containing a soilless potting media on 26 Aug. 2011 and 14 Nov. 2011. Pots were allowed to mature in the greenhouse over a 3 -month period where they were maintained at a height of 0.25 inches. Herbicide treatments were applied on $1 \mathrm{Dec} .2011$ and $8 \mathrm{Feb} .2012$ and consisted of metamifop at $0.18,0.27,0.36$, or $0.45 \mathrm{lb} /$ acre. A sequential application of each treatment was made on 22 Dec. 2011 and 29 Feb. 2012. A nontreated control was included for comparison. Clipping ceased after initial herbicide treatment and pots produced biomass for 3 weeks. Biomass above 0.25 inch was removed from each pot, dried, and weighed. This procedure was conducted again 3 weeks after sequential treatments. The rate of metamifop required to reduce bermudagrass growth $50 \%\left(G_{50}\right)$ was calculated 3 and 6 weeks after initial treatment (WAIT). Visual ratings of percent bermudagrass control were recorded weekly on a scale of $0 \%$ (no control) to $100 \%$ (completely dead bermudagrass). As metamifop rate increased, bermudagrass biomass decreased. The calculated $\mathrm{GR}_{50}$ at 3 WAIT for 'Savannah' and 'Riviera' was 0.19 and $0.14 \mathrm{lb} / \mathrm{acre}$, respectively. Nontreated control pots exhibited $0 \%$ control and produced 0.59 to $0.83 \mathrm{~g}$ of biomass at 3 WAIT, regardless of cultivar. Metamifop at 0.27 to $\mathbf{0 . 4 5}$ $\mathrm{lb} /$ acre exhibited $96 \%$ to $100 \%$ bermudagrass control at 3 WAIT, regardless of cultivar. Bermudagrass subjected to those same treatments only produced 0.01 to $0.03 \mathrm{~g}$ of biomass at 3 WAIT, regardless of cultivar. The $0.18-1 \mathrm{~b} /$ acre rate of metamifop exhibited only $9 \%$ control of 'Savannah' bermudagrass with $0.72 \mathrm{~g}$ of biomass collected, while 'Riviera' was controlled $41 \%$ with $0.38 \mathrm{~g}$ of biomass collected. The calculated $\mathrm{GR}_{50}$ at 6 WAIT for 'Savannah' and 'Riviera' was 0.13 and $0.14 \mathrm{lb} / \mathrm{acre}$, respectively. Sequential applications of metamifop at 0.27 to 0.45 $\mathrm{lb} /$ acre completely controlled bermudagrass $(100 \%)$ at 6 WAIT, while a sequential application at $0.18 \mathrm{lb}$ /acre only controlled bermudagrass $8 \%$ to $19 \%$ at 6 WAIT, regardless of cultivar. Bermudagrass subjected to $0.18 \mathrm{lb} /$ acre exhibited 0.48 to $0.56 \mathrm{~g}$ of biomass at 6 WAIT, regardless of cultivar. Metamifop shows potential as an alternative control option for common bermudagrass present within cool-season turfgrass species.

B ermudagrass is the primary warm-season turfgrass species grown in the United States (Christians, 2011). Common to home lawns, athletic fields, and golf courses, bermudagrass is adapted to the southern

\footnotetext{
${ }^{1}$ Department of Plant and Soil Science, Texas Tech University, Box 42122, Lubbock, TX 79409

${ }^{2}$ Department of Extension Plant Sciences, New Mexico State University, Box 30003, Las Cruces, NM 88003

${ }^{3}$ Department of Crop and Soil Sciences, University of Georgia, 3111 Miller Plant Sciences Building, Athens, GA 30602

${ }^{4}$ Corresponding author. E-mail: gmhenry@uga.edu.
}

and central regions of the transition zone (Christians, 2011). The abundant production of aggressive rhizomes and stolons enables bermudagrass to tolerate wear and recover from stress quicker than cool-season turf (Beard, 1973; Youngner, 1961). However, this may also make it a difficult to control weed in some turfgrass environments (Griffin et al., 1994; Johnson and Carrow, 1993). Creeping bentgrass is frequently used as a golf course putting surface in warm, temperate climates where bermudagrass is adapted to grow. Bermudagrass is capable of encroaching into putting greens from neighboring surrounds because optimum bermudagrass growth occurs from June through August when creeping bentgrass is often experiencing stress (Christians and Engelke, 1994; Turgeon, 2011). The presence of bermudagrass in creeping bentgrass greens can disrupt the playing surface and reduce aesthetic quality (Johnson and Carrow, 1993; Lowe et al., 2000).

Limited options exist for the selective control of bermudagrass in managed turfgrass. The use of siduron for the control or suppression of bermudagrass in creeping bentgrass putting greens has been inconsistent. McMaugh (1971) reported complete control of common bermudagrass in response to sequential applications of siduron at $40.11 \mathrm{lb} /$ acre at 12 -week intervals. Although 'Tifdwarf' hybrid bermudagrass $(C$. dactylon $\times$ Cynodon transvaalensis Burtt-Davy) growth was suppressed with sequential (4- to 6-week intervals) applications of siduron at $17.83 \mathrm{lb} / \mathrm{acre}$, Duble (1974) suggested additional applications would be necessary to prevent further encroachment. Siviour and Schultz (1984) observed no change or increased common bermudagrass cover in response to single or sequential applications of siduron at $44.57 \mathrm{lb} /$ acre. Johnson and Carrow (1993) reported that tank-mixing siduron with flurprimidol at $48.13+0.71 \mathrm{lb} /$ acre in March followed by $12.48+0.18 \mathrm{lb} /$ acre in April and May resulted in 83\% to $94 \%$ bermudagrass suppression by midJune. Single and sequential applications

\begin{tabular}{llll}
\hline $\begin{array}{l}\text { Units } \\
\text { To convert U.S. to SI, } \\
\text { multiply by }\end{array}$ & U.S. unit & SI unit & $\begin{array}{l}\text { To convert SI to U.S., } \\
\text { multiply by }\end{array}$ \\
\hline 9.3540 & gal/acre & $\mathrm{L} \cdot \mathrm{ha}^{-1}$ & 0.1069 \\
2.54 & inch $(\mathrm{es})$ & $\mathrm{cm}$ & 0.3937 \\
1.1209 & $\mathrm{lb} / \mathrm{acre}$ & $\mathrm{kg} \cdot \mathrm{ha}^{-1}$ & 0.8922 \\
28.3495 & $\mathrm{oz}$ & $\mathrm{g}$ & 0.0353 \\
6.8948 & $\mathrm{psi}$ & $\mathrm{kPa}$ & 0.1450 \\
$\left({ }^{\circ} \mathrm{F}-32\right) \div 1.8$ & ${ }^{\circ} \mathrm{F}$ & ${ }^{\circ} \mathrm{C}$ & $\left({ }^{\circ} \mathrm{C} \times 1.8\right)+32$
\end{tabular}


of ethofumesate (0.36 to $1.52 \mathrm{lb} /$ acre $)+$ flurprimidol (0.18 to $0.71 \mathrm{lb} / \mathrm{acre})$ made from March until May exhibited $88 \%$ to $99 \%$ bermudagrass suppression by mid-June. Sequential applications of fenoxaprop at $0.06 \mathrm{lb} /$ acre in April, May, and June resulted in $75 \%$ suppression of common bermudagrass by mid-June, but only $14 \%$ and $26 \%$ suppression of 'Tifway' and 'Tifgreen' hybrid bermudagrass, respectively (Johnson and Carrow, 1993). Doroh et al. (2011) observed similar control (32\%) of 'Tifway' bermudagrass 9 WAIT following sequential applications of fenoxaprop at $0.09 \mathrm{lb} /$ acre. Sequential treatments of fenoxaprop alone or in combination with triclopyr resulted in the lowest percent cover of common bermudagrass (3\% to $19 \%$ ) at the end of the growing season (Cudney et al., 1997).

Herbicide rates required for bermudagrass control often result in unacceptable levels of creeping bentgrass phytotoxicity. Johnson and Carrow (1993) observed $50 \%$ to $77 \%$ and $23 \%$ to $45 \%$ phytotoxicity on 'Penncross' creeping bentgrass $10 \mathrm{~d}$ after treatment (DAT) with fenoxaprop at $0.12 \mathrm{lb} /$ acre and ethofumesate + flurprimidol at $1.52+$ $0.71 \mathrm{lb} /$ acre, respectively. Higgins et al. (1987) reported that fenoxaprop at 0.06 and $0.13 \mathrm{lb} /$ acre did not reduce creeping bentgrass color ratings below 4.5, while fluazifop at $0.09,0.18$, and $0.27 \mathrm{lb} /$ acre reduced creeping bentgrass color ratings below 2.9 14 DAT. Henry and Hart (2004) observed a $20 \%$ and $40 \%$ reduction in clipping weight 4 weeks after treatment (WAT) of 'L-93' creeping bentgrass in response to fenoxaprop at 0.06 and $0.13 \mathrm{lb} /$ acre. Reductions in turfgrass quality not only affect creeping bentgrass aesthetic appearance but may also reduce its competition, making it more susceptible to invasion from other weeds [e.g., annual bluegrass (Poa annua L.)] (Johnson, 1984; Turner et al., 1979).

Metamifop is a postemergence aryloxyphenoxypropionic acid herbicide used for the control of a wide range of annual and perennial grass weeds in cereal crops and rice (Hae-Jin et al., 2002; Moon et al., 2007). Doroh et al. (2011) observed 36\% 'Tifway' hybrid bermudagrass control 9 WAIT in response to sequential applications of metamifop at $0.36 \mathrm{lb} /$ acre. Tank-mixing metamifop at
$0.36 \mathrm{lb} /$ acre with triclopyr at 1 $\mathrm{lb} /$ acre increased bermudagrass control to $93 \%$ at 9 WAIT (Doroh et al., 2011). Askew and Goddard (2010) and Alea et al. (2010) observed minimal turfgrass injury ( $\leq$ $10 \%)$ when metamifop was applied to creeping bentgrass at $0.36 \mathrm{lb} /$ acre. Furthermore, Gomez de Barreda et al. (2013) reported that metamifop at $0.18 \mathrm{lb} /$ acre applied 4 weeks after seeding (WAS) 'Penn A-4' creeping bentgrass did not reduce turfgrass cover. Metamifop could potentially be an alternative chemical control for the removal of bermudagrass in cool-season turf with little to no phytotoxicity. Therefore, the objective of our research was to evaluate the efficacy of metamifop for common bermudagrass control in a greenhouse environment.

\section{Materials and methods}

Experiments were conducted at the Plant and Soil Science greenhouse facility at Texas Tech University in Lubbock in 2011 and 2012. 'Riviera' common bermudagrass (Johnston Seed Co., Enid, OK) and 'Savannah' common bermudagrass (Turf Seed, Gervais, OR) were seeded at 218 $\mathrm{lb} /$ acre into 4 -inch square pots containing a soilless potting media (Sun Gro Horticulture, Vancouver, BC, Canada) on 26 Aug. 2011 and 14 Nov. 2011. Fertilizer [7N-3.1P5.8K (Green Spec Fertilizer; Grigg Brothers, Albion, ID)] was applied at the time of seeding at a rate of $22 \mathrm{lb} /$ acre nitrogen and monthly thereafter until the conclusion of each trial. Greenhouse temperatures were maintained at $93 / 80{ }^{\circ} \mathrm{F}$ (day/night) with average midday (1200 and $1300 \mathrm{HR}$ ) solar radiation ranging from 636 to $754 \mu \mathrm{mol} \cdot \mathrm{m}^{-2} \cdot \mathrm{s}^{-1}$. Irrigation was supplied through an overhead irrigation system calibrated to deliver $\approx 1.5 \mathrm{inch} /$ week of water. Pots were allowed to mature in the greenhouse over a 3-month period. Bermudagrass was maintained at 0.25 inch with handheld, electric grass shearers (Oster Showmaster; Jarden Corp., Rye, NY) during establishment and pots were trimmed 24 h before herbicide application. This mowing height was chosen to simulate bermudagrass encroachment into a creeping bentgrass putting green collar. Treatments were arranged in a randomized complete block design with five replications. The experiment was blocked against a temperature gradient imposed from the presence of a wet wall evaporative cooling system at one end of the greenhouse. Herbicides were applied with a carbon dioxide backpack sprayer equipped with XR8004VS nozzle tips (Teejet; Spraying Systems Co., Wheaton, IL) calibrated to deliver $40 \mathrm{gal} / \mathrm{acre}$ at 32 psi. Herbicide treatments were applied on 1 Dec. 2011 and 8 Feb. 2012 and consisted of metamifop (Dongbu Financial Center, Gangnam-Ga, Seoul, Korea) at $0.18,0.27,0.36$, or 0.45 lb/acre. A sequential application of each treatment was made on 22 Dec. 2011 and 29 Feb. 2012. A nontreated control was included for comparison.

Bermudagrass pots were cut to 0.25 inch after 3 weeks of growth (before sequential treatments), biomass was dried, and weighed. This procedure was conducted again 3 weeks after sequential treatments. Previous research evaluated sequential herbicide treatments every 3 to 4 weeks for bermudagrass control (Ferrell et al., 2005; Johnson, 1988; Lewis et al., 2010). Visual ratings of percent bermudagrass control were recorded weekly on a scale of $0 \%$ (no control) to $100 \%$ (completely dead bermudagrass). No significant run by treatment interactions were observed so data were pooled across runs and subjected to analysis of variance $(P=0.05)$ using mixed model methodology provided by SAS (version 9.2; SAS Institute, Cary, NC) with sums of squares partitioned to reflect a split plot treatment structure. Bermudagrass cultivar was considered the main plot and metamifop rate was considered the subplot. Where main plot effects were significant, nonlinear regressions were used to explain the relationship of measured responses to increased metamifop rate (SigmaPlot 12.5; Systat Software, San Jose, CA). Difference among individual rates of metamifop were separated using Fisher's protected least significant difference test at $P=0.05$. The rate of metamifop required to reduce bermudagrass growth $50 \%$ was calculated 3 and 6 WAIT. Confidence intervals $(95 \%)$ were calculated for $\mathrm{GR}_{50}$ values using SigmaPlot.

\section{Results and discussion}

Bermudagrass cultivar and metamifop rate explained a significant 
amount of the variability present in biomass data at 3 WAIT ['Savannah' $R^{2}=0.80$, 'Riviera' $R^{2}=0.90$ (Fig. 1)]. As metamifop rate increased, bermudagrass biomass decreased. The calculated $\mathrm{GR}_{50}$ at 3 WAIT for 'Savannah' and 'Riviera' was 0.19 and $0.14 \mathrm{lb} /$ acre, respectively. The nontreated control pots exhibited $0 \%$ control and 0.59 to $0.83 \mathrm{~g}$ of biomass at 3 WAIT, regardless of cultivar (Figs. 1 and 2 ). Metamifop at 0.27 to $0.45 \mathrm{lb} /$ acre resulted in $98 \%$ to $100 \%$ bermudagrass control at 3 WAIT, regardless of cultivar (Fig. 2). Similar control $(88 \%$ to $99 \%)$ was observed with single and sequential applications of ethofumesate $(0.36$ to 1.52 $\mathrm{lb} /$ acre $)+$ flurprimidol $(0.18$ to $0.71 \mathrm{lb} /$ acre) (Johnson and Carrow, 1993). Bermudagrass subjected to metamifop at 0.27 to $0.45 \mathrm{lb} /$ acre only exhibited 0.01 to $0.03 \mathrm{~g}$ of biomass at 3 WAIT, regardless of cultivar. The 0.18 - $\mathrm{lb} /$ acre rate of metamifop exhibited only $9 \%$ control of 'Savannah' bermudagrass with $0.72 \mathrm{~g}$ of biomass collected, while 'Riviera' was controlled $41 \%$ with $0.38 \mathrm{~g}$ of biomass collected.

Bermudagrass cultivar and metamifop rate explained a significant amount of the variability present in biomass data at 6 WAIT ['Savannah' $R^{2}=0.95$, 'Riviera' $R^{2}=0.94$ (Fig. 3)]. As metamifop rate increased, bermudagrass biomass decreased. The calculated $\mathrm{GR}_{50}$ at 6 WAIT for 'Savannah' and 'Riviera' was 0.13 and 0.14 $\mathrm{lb} /$ acre, respectively. Sequential applications of metamifop at 0.27 to 0.45 $\mathrm{lb} /$ acre completely controlled bermudagrass $(100 \%)$ at 6 WAIT. However, Doroh et al. (2011) observed only 36\% 'Tifway' hybrid bermudagrass control at 9 WAIT in response to sequential applications of metamifop at $0.36 \mathrm{lb} /$ acre. A sequential application of metamifop at $0.18 \mathrm{lb} /$ acre only controlled bermudagrass $8 \%$ to $19 \%$ and yielded 0.48 to $0.56 \mathrm{~g}$ of biomass at 6 WAIT, regardless of cultivar (Figs. 3 and 4 ).

Methods employed in this research may have resulted in greater bermudagrass control than observed by other researchers. Research conducted by Doroh et al. (2011) took place in the field, while our research was conducted in the greenhouse. Plants grown under greenhouse conditions are often more susceptible to herbicides and therefore exhibit higher

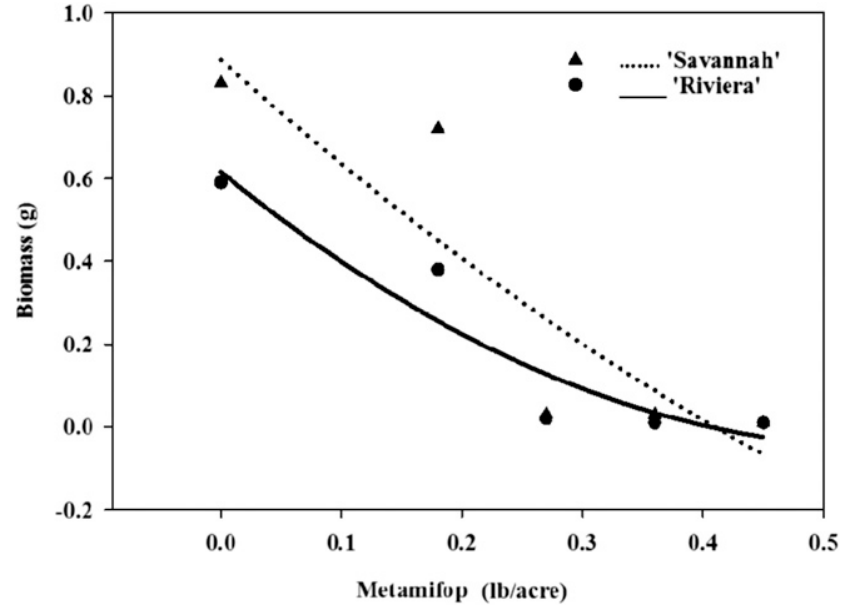

Fig. 1. Above-ground biomass of 'Savannah' and 'Riviera' common bermudagrass 3 weeks after initial treatment (WAIT) in response to metamifop during 2011-12 in Lubbock, TX. Quadratic equations: 'Savannah' $\mathrm{y}=0.01 \mathrm{x}^{2}-0.12 \mathrm{x}+3.27$, $R^{2}=0.80$; 'Riviera' $y=0.01 x^{2}-0.11 x+2.26, R^{2}=0.90$. The calculated growth reduction $\left(G_{50}\right)$ for 'Savannah' and 'Riviera' was $0.19(95 \%$ confidence interval of $-0.36,1.17)$ and $0.14(95 \%$ confidence interval of $-0.01,0.67) \mathrm{lb} / \mathrm{acre}$, respectively; $1 \mathrm{lb} /$ acre $=1.1209 \mathrm{~kg} \cdot \mathrm{ha}^{-1}, 1 \mathrm{~g}=0.0353 \mathrm{oz}$.

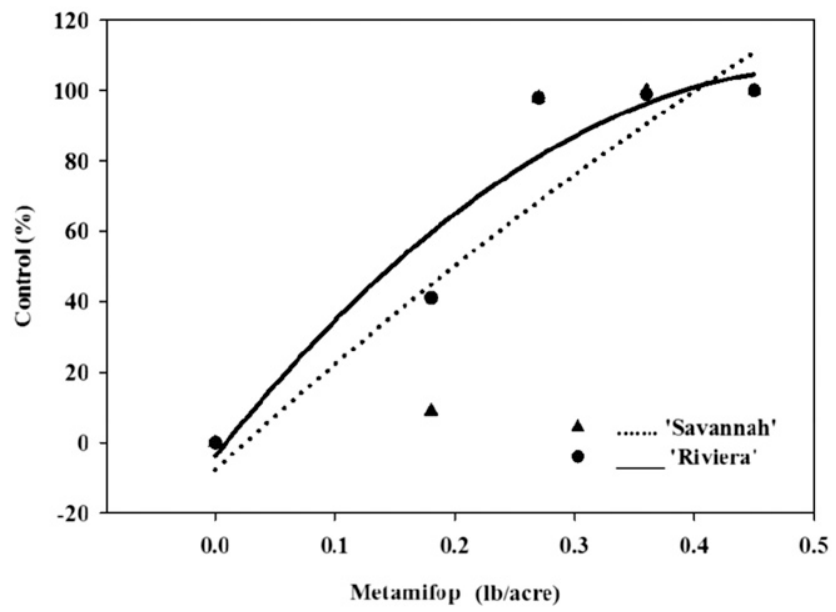

Fig. 2. Percent control of 'Savannah' and 'Riviera' common bermudagrass 3 weeks after initial treatment (WAIT) in response to metamifop during 2011-12 in Lubbock, TX. Quadratic equations: 'Savannah' $\mathrm{y}=-0.06 \mathrm{x}^{2}+1.02 \mathrm{x}-7.78, R^{2}=$ 0.78 ; 'Riviera' $\mathrm{y}=-0.06 \mathrm{x}^{2}+1.42 \mathrm{x}-3.86, R^{2}=0.92 ; 1 \mathrm{lb} /$ acre $=1.1209 \mathrm{~kg} \cdot \mathrm{ha}^{-1}$.

levels of phytotoxicity. Lingenfelter and Curran (2007) observed 98\% control of wirestem muhly [Mublenbergia frondosa (Poir.) Fern.] in the greenhouse in response to glyphosate $(0.37$ and $0.75 \mathrm{lb} /$ acre) at $4 \mathrm{WAT}$. The same applications made in the field only exhibited $60 \%$ to $87 \%$ control at 4 WAT. Plant age and cultivar may also have an effect on herbicide efficacy. Doroh et al. (2011) examined the effect of metamifop on 4-year-old 'Tifway' hybrid bermudagrass, while common bermudagrasses used in our experiments were only 3 months old. Schuster et al. (2007) observed $80 \%$ control of 1 -inch common lambsquarters (Chenopodium album L.) in response to glyphosate at $0.98 \mathrm{lb} /$ acre, but only $55 \%$ control of 3 -inch and 6 -inch plants. Common bermudagrass cultivars were used in our research, while 'Tifway' hybrid bermudagrass was evaluated in Doroh et al. (2011). Johnson and Carrow (1993) reported that sequential applications of fenoxaprop at $0.06 \mathrm{lb} /$ acre in April, May, and June resulted in $75 \%$ suppression of common bermudagrass by midJune, but only $14 \%$ and $26 \%$ suppression of 'Tifway' and 'Tifgreen' bermudagrass, respectively. 


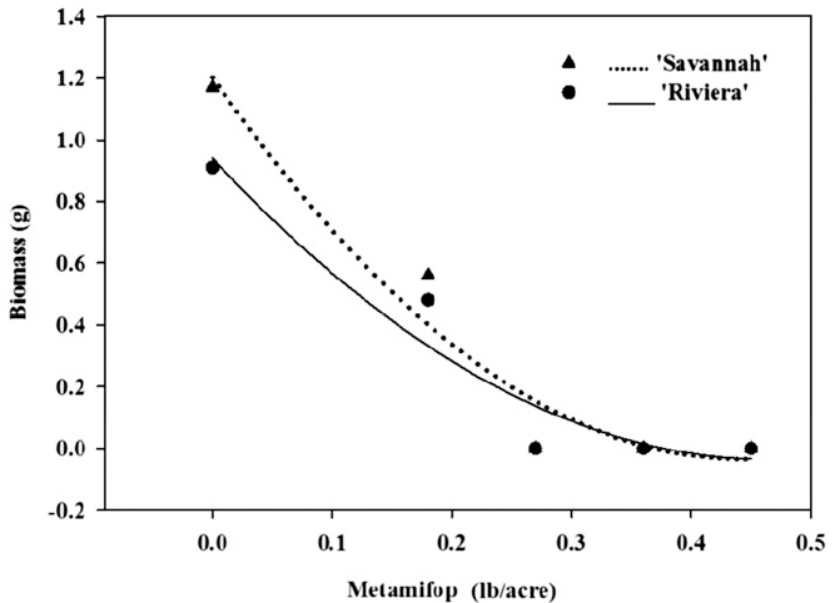

Fig. 3. Above-ground biomass of 'Savannah' and 'Riviera' common bermudagrass 6 weeks after initial treatment (WAIT) in response to metamifop during 2011-12 in Lubbock, TX. Quadratic equations: 'Savannah' $y=-0.01 x^{2}-0.25 x-1.20$, $R^{2}=0.95$; 'Riviera' $\mathrm{y}=0.01 \mathrm{x}^{2}-0.19 \mathrm{x}-3.46, R^{2}=0.94$. The calculated growth reduction $\left(\mathrm{GR}_{50}\right)$ for 'Savannah' and 'Riviera' was 0.13 (95\% confidence interval of $0.11,1.03)$ and $0.14(95 \%$ confidence interval of $0.02,0.83) \mathrm{lb} / \mathrm{acre}$, respectively; $1 \mathrm{lb} /$ acre $=1.1209 \mathrm{~kg} \cdot \mathrm{ha}^{-1}, 1 \mathrm{~g}=0.0353 \mathrm{oz}$.

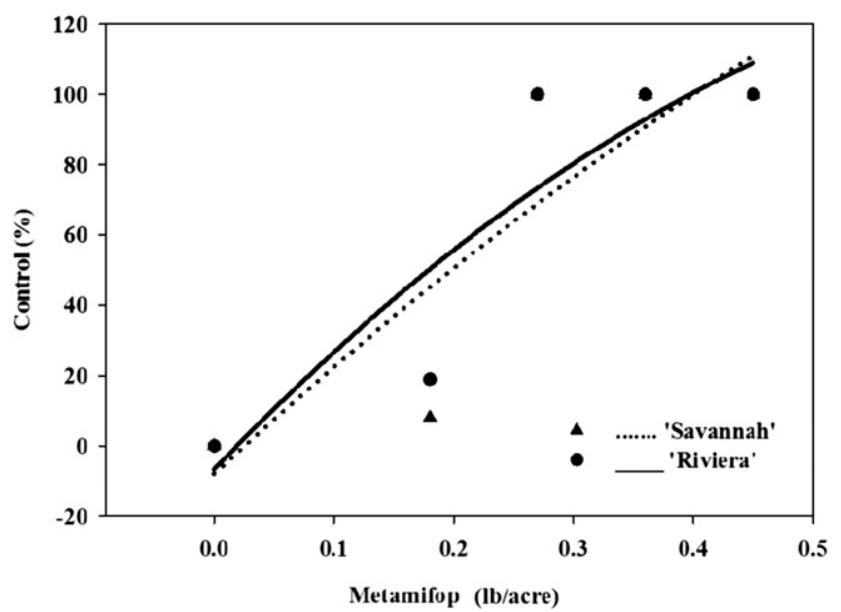

Fig. 4. Percent control of 'Savannah' and 'Riviera' common bermudagrass 6 weeks after initial treatment (WAIT) in response to metamifop during 2011-12 in Lubbock, TX. Quadratic equations: 'Savannah' $\mathrm{y}=-0.06 \mathrm{x}^{2}+1.05 \mathrm{x}-8.03, R^{2}=$ 0.77 ; 'Riviera' $y=-0.03 x^{2}+1.18 x-6.72, R^{2}=0.82 ; 1 \mathrm{lb} /$ acre $=1.1209 \mathrm{~kg} \cdot \mathrm{ha}^{-1}$.

Metamifop shows potential for use as an alternative for the control of bermudagrass present in cool-season turf. In the current study, excellent bermudagrass control ( $98 \%$ to $99 \%)$ was observed 3 WAIT in response to metamifop at $0.27 \mathrm{lb} /$ acre. Askew and Goddard (2010) observed minimal turfgrass injury $(\leq 10 \%)$ when metamifop was applied to a creeping bentgrass putting green at 0.36 lb/acre, while Alea et al. (2010) reported no significant injury to creeping bentgrass maintained at 0.36 inch in response to sequential applications of control 8 WAS when applied 1, 2, or 3 WAS, but treatments at 4 WAS did not reduce creeping bentgrass cover. Seedling bentgrass safety to metamifop may allow turfgrass managers to entwine reseeding practices and sequential herbicide applications. This may further increase creeping bentgrass competition with encroaching bermudagrass and enhance overall control.

\section{Literature cited}

Alea, S., S. Hart, and C. Mansue. 2010. Weed control and cool season turfgrass response to metamifop. Proc. Northeastern Weed Sci. Soc. 64:77-78.

Askew, S. and M. Goddard. 2010. Selective grass weed control in turf with metamifop. Proc. Northeastern Weed Sci. Soc. 64:72 (abstr.).

Beard, J.B. 1973. Turfgrass: Science and culture. Prentice Hall, New York, NY.

Christians, N.E. 2011. Fundamentals of turfgrass management. 4th ed. Wiley, Hoboken, NJ.

Christians, N.E. and M.C. Engelke. 1994. Choosing the right grass to fit the environment, p. 99-112. In: A.R. Leslie (ed.). Handbook of integrated pest management for turfgrass and ornamentals. Lewis Publ., Boca Raton, FL.

Cudney, D.W., C.L. Elmore, V.A. Gibeault, and J.S. Reints. 1997. Common bermudagrass (Cynodon dactylon) management in cool-season turfgrass. Weed Technol. 11: 478-483.

Doroh, M.C., J.S. McElroy, and E. van Santen. 2011. Evaluation of new aryloxyphenoxypropionate herbicides for control of bermudagrass in zoysiagrass. Weed Technol. 25:97-102.

Duble, R.L. 1974. Bentgrass greens in the hot, humid south. Golf Superintendent 42(3):36-38.

Ferrell, J.A., T.R. Murphy, and D.C. Bridges. 2005. Postemergence control of hybrid bermudagrass (Cynodon transvaalensis Burtt-Davy $\times$ Cynodon dactylon). Weed Technol. 19:636-639.

Gomez de Barreda, D., J. Yu, and P.E. McCullough. 2013. Seedling tolerance of cool-season turfgrasses to metamifop. HortScience 48:1313-1316.

Griffin, K.A., R. Dickens, and M.S. West. 1994. Imazapyr for common bermudagrass control in sod fields. Crop Sci. 34: 202-207.

Hae-Jin, C., H. Kim, H. Kim, S. Kim, D. Lee, J. Hur, and S. Kim. 2002. Postemergence weed control with a mixture of 


\section{Research Reports}

pyrazosulfuron and metamifop in rice (Oryza sativa L. cv. Tongjin). J. Agr. Sci. 13:89-96.

Henry, G.M. and S.E. Hart. 2004. Velvet and creeping bentgrass tolerance to fenoxaprop. HortScience 39:1768-1770.

Higgins, J.M., L.B. McCarty, T. Whitwell, and L.C. Miller. 1987. Bentgrass and bermudagrass putting green turf tolerance to postemergence herbicides. HortScience $22: 248-250$.

Johnson, B.J. 1984. Influence of nitrogen on recovery of bermudagrass (Cynodon dactylon) treated with herbicides. Weed Sci. 32:819-823.

Johnson, B.J. 1988. Glyphosate and SC0224 for bermudagrass (Cynodon spp.) cultivar control. Weed Technol. 2:2023.

Johnson, B.J. and R.N. Carrow. 1993. Bermudagrass (Cynodon spp.) suppression in creeping bentgrass (Agrostis stolonifera) with herbicide-flurprimidol treatments. Weed Sci. 1:120-126.

Lewis, D.F., J.S. McElroy, J.C. Sorochan, T.C. Mueller, T.J. Samples, and G.K. Breeden. 2010. Efficacy and safening of aryloxyphenoxypropionate herbicides when tank-mixed with triclopyr for bermudagrass control in zoysiagrass turf. Weed Technol. 24:489-494.

Lingenfelter, D.D. and W.S. Curran. 2007. Effect of glyphosate and several ACCase-inhibitor herbicides on wirestem muhly (Mublenbergia frondosa) control. Weed Technol. 21:732-738.

Lowe, T., B. McCarty, and T. Whitwell. 2000. Bermudagrass encroachment: A menace on bentgrass greens. Golf Course Mgt. 68(9):68-71.

McMaugh, P. 1971. Control of encroachment of Agrostis spp. swards by warm-season turfgrasses. J. Sports Turf Res. Inst. 47:33-40.

Moon, J.K., Y.S. Keum, E.C. Hwang, B.S. Park, H.R. Chang, Q.X. Li, and J. H. Kim. 2007. Hapten synthesis and antibody generation for a new herbicide, metamifop. J. Agr. Food Chem. 55:5416-5422.

Parker, E.T., J.S. McElroy, and M.L. Flessner. 2015. Smooth crabgrass and goosegrass control with metamifop in creeping bentgrass. HortTechnology 25: 757-761.

Schuster, C.L., D.E. Shoup, and K. AlKhatib. 2007. Response of common lambsquarters (Chenopodium album) to glyphosate as affected by growth stage. Weed Sci. 55:147-151.

Siviour, T.R. and G.F. Schultz. 1984. Response of bermudagrass (Cynodon dactylon) to siduron. Weed Sci. 32:178180.

Turgeon, A.J. 2011. Turfgrass management. 9th ed. Pearson Education, Upper Saddle River, NJ.

Turner, T.R., D.V. Waddington, and T.L. Watschke. 1979. The effect of soil fertility levels on dandelion and crabgrass encroachment on Merion kentucky bluegrass. Proc. Northeastern Weed Sci. Soc. 33:280-286.

Youngner, V.B. 1961. Accelerated wear tests on turfgrasses. Agron. J. 53:217218. 